PRODUCTION

ENGINEERING ARCHIVES
2015, No 4, pp 6-9

ISSN 2353-5156 (print version)

ISSN 2353-7779 (online version)

\title{
The use of managerial grid to analyse the relationship between assessment of human and production or service issues in various companies
}

\author{
Krzysztof Knop ${ }^{1}$ \\ ${ }^{1}$ Institute of Production Engineering, Faculty of Management, Czestochowa University of Technology, Armii Krajowej 19B, 42-201 \\ Czestochowa, Poland, e-mail: kknop@poczta.fm
}

\begin{abstract}
In the article the results of BOST method usage was presented to analyse the importance of human and production/services issues in three different companies - a steelworks, a plastic-processing and a retail chain company. The importance of human and production/service issues was analysed by using the concept of the managerial grid. The relation between workers answers with the use of managerial grid after division answers was analysed into four and three areas. The frequency of occurrence of ratings to determine a degree of perception of importance of human and production/service issues in these companies was analysed.
\end{abstract}

Key words $-9^{\text {th }}$ Toyota management principle, BOST research, managerial gird, human and production/service issues

\section{1. $9^{\text {th }}$ Toyota management principle and its evaluation by BOST research usage}

The $9^{\text {th }}$ Toyota management principle aims to: 'grow leaders who thoroughly understand the work, live the philosophy, and teach it to others.' According to this principle, a fundamental task of a Toyota leader is to build a learning organization, thus strengthening a particularly strong element of culture in this company.

There is a popular saying in Toyota: 'before we started building cars, we'd built people'. The goal for each leader is to develop people so that they contribute substantially to achieve joint goals and they can think the Toyota way and follow it at each step in the corpo- rate ladder. Employees must be educated and trained: they have to maintain a learning organization. The company which grows their own leaders and finds 'building learning organization' as an ultimate goal for the leadership, sets foundation for real long-term successes (LIKER J.K. 2005). This is one distinct difference between Toyota and nearly every other company - leaders genuinely live the philosophy and have the capability to teach it either by direct methods or 'leading by example.' (WALTERS CH. 2012). When an organization establishes common thinking and common direction with all the leaders within the organization, the company becomes more stable and there is no ground lost in continuous improvement or a change in 
the company's direction before, during or after the transition (WRYE M. 2013).

The attempt to transform 14 principles of Toyota management into questions was reflected in BOST survey (BORKOWSKI S.2012a; BORKOWSKI S.2012b). Evaluation of the $9^{\text {th }}$ Toyota management principle was presented in BOST survey in E9 question: Assess using scale 1 to 9 , the importance, in your company, of:

- $₫ \square$ human issues,, $\mathrm{ZP} \square$ duction/service issues. where: 1 - lack of interest, 9 - high interest.

\section{Managerial grid in different compa- nies}

\subsection{Analysis of importance of human and pro- duction interest in the steel company}

The structure of votes on the managerial grid connected to human and production interest could be analysed in different way(BORKOWSKI S., PIESZCZOCH D. 2009). For example, by using statistical parameters (BORKOWSKI S., BLAŠKOVÁ M., HITKA M. 2009) or by using different kinds of graphs only to show in the best way the relation between data.

On the basis of the collected answers by steelwork's employees Fig. 1a was prepared to illustrate numerical relationships between the assessment of interest in human problems and production-related issues. In the next step managerial grid was divided into four parts (Fig. 1b): I ${ }^{\text {st }}$ part - low level of importance of human and production issues, $\mathrm{II}^{\text {nd }}$ part low level of importance of human problems, high level of importance of production issues, III $^{\text {rd }}$ part - high level of importance of human problems, low level of importance of production issues, $\mathrm{IV}^{\text {th }}$ part - high level of importance of human and production issues.
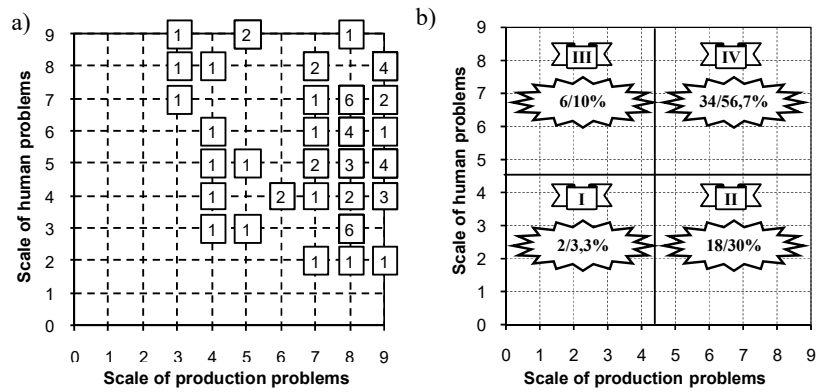

Fig. 1. Analysis of managerial grid: a) numerical structure of votes, b) percentage structure of votes after its division into four areas. Refers to the steel company.

Source: own study.
Among the 60 workers questioned, 34 workers (56.7\%) reported a high level of importance of both production and human issues in the analysed company, 18 respondents $(30 \%)$ claimed that more emphasis is on production problems rather than on human ones.

In the next step the managerial grid was divided into three areas. The first area shows a combination of answers with identical importance for human and production issues. II $^{\text {nd }}$ area contains the answers according to which more importance is attached to production issues rather than to human problems. On the other hand, III ${ }^{\text {rd }}$ area, through combination of the answers, points to a higher focus on human issues as compared to production/services ones. The results of this analysis based on data collected from the company are presented in Fig. 2.

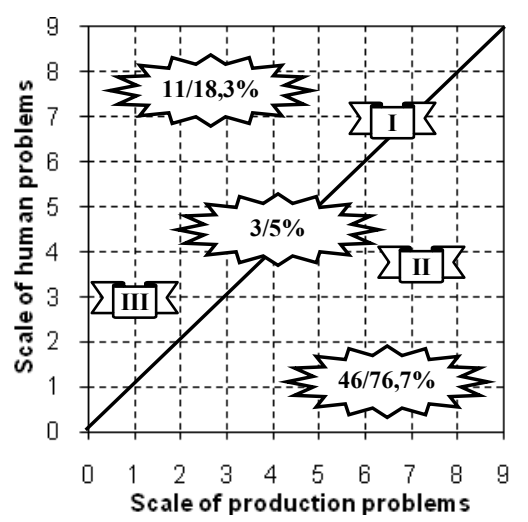

Fig. 2. Numerical and percentage structure of votes after its division into three areas. Refers to the steel company.

Source: own study.

As results from the relationships determined between employees' answers, the company puts more emphasis on production issues rather than on human problems (according to $76.7 \%$ of respondents). Only 11 from 60 workers (18.3\%) emphasized more interest in employee problems. Equal importance of 'production' and 'humans' was assessed by $5 \%$ of the workers. Observation of the results contained in Fig. 2 from the standpoint of the most frequent combinations of answers reveals that they were 8-3 (6 times and 8-7 (6 times), where the first number means importance of production issues. As results from this fact, employees sense a trend of the company to focus on production issues (high assessment (8)), whereas the standpoint of employees towards human issues in the company is not that unequivocal - low assessment of 3 and high assessment of 7 . 


\subsection{Analysis of importance of human and pro- duction interest in the plastics processing com- pany}

The assessment of importance of human problems and production issues in the company which processes plastics was determined based on the results of answers of 84 employees. The diagram which illustrates votes is presented in Fig. 3a.
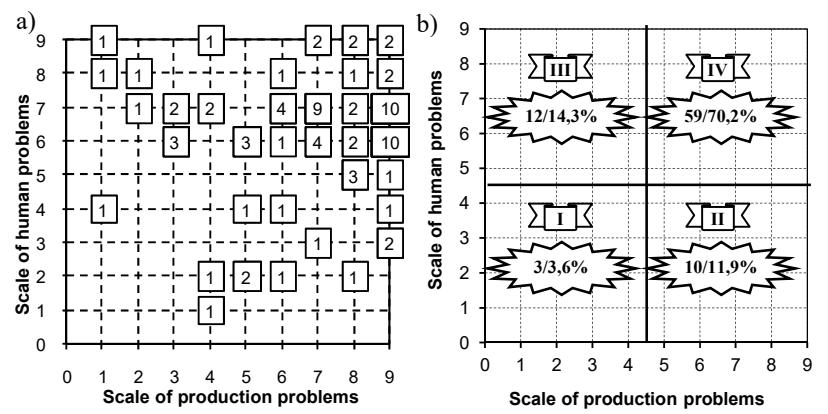

Fig. 3. Analysis of managerial grid: a) numerical structure of votes, b) percentage structure of votes after its division into four areas. Refers to the plastics processing company.

Source: own study.

As results from Fig. 3 a distinct focus in the company is on production and human issues - the overwhelming majority of answers $(70.2 \%)$ are accumulated in $\mathrm{IV}^{\text {th- }}$ part. If we assess the importance of production and human issues separately in the company, it was noted that the human issues scored slightly better than production $-84.5 \%$ in comparison to $82.1 \%$.

The answers grouped according to three parts are presented in Fig. 4.

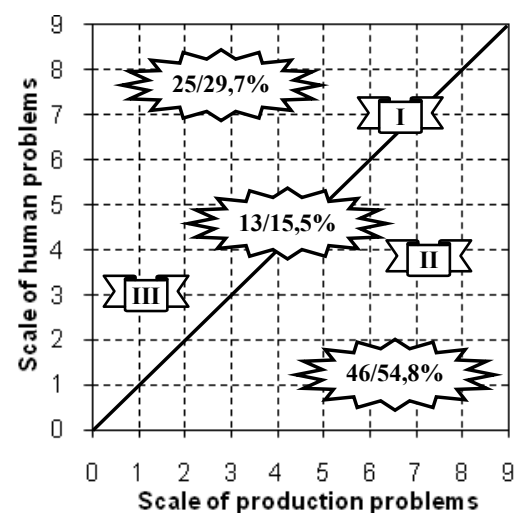

Fig. 4. Numerical and percentage structure of votes after its division into three areas. Refers to the plastics processing company.

Source: own study.
Results of classification of answers to three parts revealed that, from the standpoint of employees, the enterprise attaches great importance to widely understood production issues (54.8\%). $29.7 \%$ of the respondents observed more interest in human problems in the enterprise. In consideration of relationships between answers, one can note that the most popular arrangement are 9-6 (10 times), 9-7 (10 times) and 7-7 (9 times). Production issues are mainly in the first place in the company (according to the employees), whereas human problems are also very important - a high assessment of 6-7.

\subsection{Analysis of importance of human and ser- vices interest in the retail chain}

In order to assess the level of interest in human and service-related issues in the retail chain, the BOST opinion survey was conducted with 65 respondents from the analysed company. The results containing answers and their division to the four parts are presented in Fig. 5.
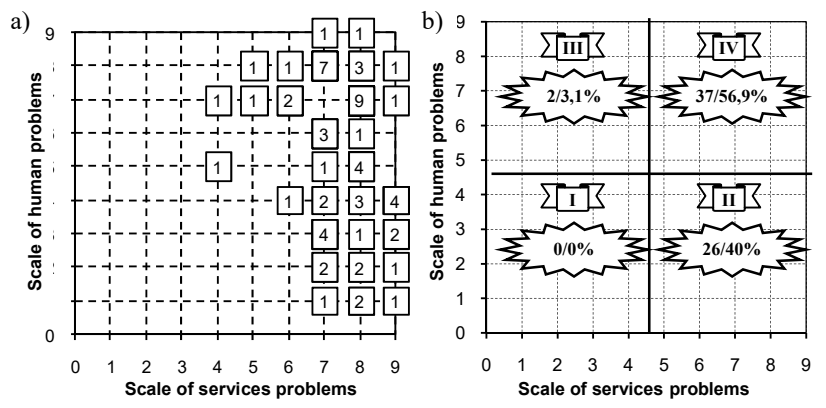

Fig. 5. Analysis of managerial grid: a) numerical structure of votes, b) percentage structure of votes after its division

into four areas. Refers to the service sector company. Source: own study.

As a result of calculations of the answers, one can assume that the investigated entity, according to $56.9 \%$ of the employees, shows a high level of interest in both service-related issues and human problems. According to $40 \%$ of the respondents, the focus in the enterprise is more on services rather than on human problems.

Graphical presentation percentage votes structure (SELEJDAK J., DYJA P. 2009;STOBIECKA K., BORKOWSKI S. 2008; BORKOWSKI S., MAZUR M. 2008) according to three parts is presented in Fig. 6. 


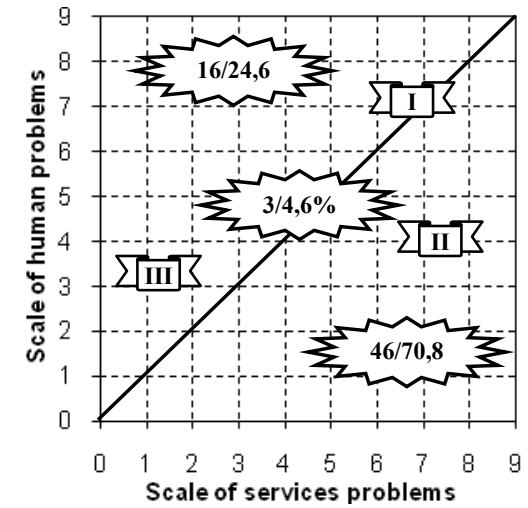

Fig. 6. Numerical and percentage structure of votes after its division into three areas. Refers to the service sector company.

Source: own study.

Figure 6 illustrates the advantage of service-related issues over human problems. $70.8 \%$ of combinations of answers pointed to a relatively higher focus on services rather than on human issues. 16 employees out of 65 , i.e. $24.6 \%$ assessed a relatively higher importance of human issues. The emphasis on both issues was found by merely $4.6 \%$.

\section{Summary}

The analysis of answers to the question E9 in the BOST questionnaire acquired much valuable information about the interest in human problems and production/service issues in all the analysed companies. The assessment of the company was made by the most important resource in each company - employees. Visualization of the results in diagrams in the form of managerial grid and then division into parts (3 and 4) allowed for unequivocal determination of importance of the researched problem. The results from the managerial grid also allow for the conclusion that all the analysed companies put great emphasis on realization of production/service issues, however, human problems are also of a high priority. Of the three companies, the best situation is observed in the company from the plastics processing industry, where $70.2 \%$ of the employees confirm a high interest in human and production issues, of which $15.5 \%$ of the respondents assess both issues at the same level of realization. The remaining two companies also show high results, at the level of $56.7 \%$ and $56.9 \%$, relating to $\mathrm{IV}^{\text {th }}$ part. In all the analysed companies, one can observe, however, an advantage of answers pointing to more interest in production/services rather than human issues. Therefore, creating and analysing the managerial grid based on the BOST research allows one to determine the management style in the companies from the standpoint of interest in core activities (production/services) and human issues. Answers to the E9 question might become an essential source of information for managers in terms of the degree of perception of the company's strategies by the employees.

\section{Literature}

1. BoRKOwSKI S. 2012a. Zasady zarzadzania Toyoty w pytaniach. Wyniki Badań BOST. Wydawnictwo PTM. Warszawa.

2. BoRKOWSKI S. 2012b. Toyotaryzm. Wyniki badań BOST. Wydawnictwo PTM. Warszawa.

3. BorkowsKi S., BlAŠKOVÁ M., HitKA M. 2009. Toyotarity. Motivation features of managers. BORKOWSKI S., BlašKOVÁ M., HitKA M. (ed.).Yurii V. Makovetsky. Dnipropetrovsk.

4. BORKOWSKI S., KNOP K. 2009.Statistical Analysis of Initial Data for Determination of Managerial Grid. Chapter 4. In: Toyotarity. Styles of Management. Borkowski S., Shevtsova O. J.(ed.).Yurii V. Makovetsky. Dnipropetrovsk.

5. Borkowski S., PIESzCZOCH D. 2009. Concepts of Leadership Maps and Managerial Grid.In: Toyotarity. Styles of Management. Borkowski S., Shevtsova O. J.(ed.).Yurii V. Makovetsky. Dnipropetrovsk.

6. LIKER J.K. 2005. Droga Toyoty. 14 zasad zarzadzania wiodacej firmy produkcyjnej świata. MT Biznes. Warszawa.

7. SelejdaK J., Dyja P. 2009.Assessment of crew knowledge of strategic areas and also areas requiring improvement.Chapter 6.In: Evaluation of Production Processess.Borkowski S., Novák A. (ed.). Novosibirsk State Technical University.Novosibirsk.

8. StOBIECKA K., BorkowsKi S. 2008. Problems of production management in window production company in staff's judgement. Chapter 8. In: Quality Improvement and Machines Exploitation. Borkowski S., Kliber J. (ed.). Publishing and Press Association of Universities Russia. Saint Petersburg.

9. WAlters CH. 2012. Toyota Way Principle 9: Growing and Developing Leaders. Available on: http://leanblitzconsulting.com/2012/07/toyota-wayprinciple-9-growing-and-developing-leaders/

10. Wrye M. 2013. Comparing the Five Lean Principles to the Toyota 14 Principles.Available on: https://beyondlean.files.wordpress.com/2013/02/compar ison-of-lean-and-toyota-principles-for-download.pdf 